\title{
Fauna Capung Di Bukit Cogong Kabupaten Musi Rawas
}

\author{
Merti Triyanti ${ }^{1}$, Destien Atmi Arisandy ${ }^{2}$ \\ ${ }^{1}$ Program Studi Pendidikan Biologi, STKIP PGRI Lubuklinggau, Lubuklinggau, Indonesia, \\ email: mertitriyanti28@gmail.com \\ ${ }^{2}$ Program Studi Pendidikan Biologi, STKIP PGRI Lubuklinggau, Lubuklinggau, Indonesia, \\ email: destienatmiarisandy@gmail.com
}

APA Citation: Triyanti, M., \& Arisandy, D.A. (2020). Fauna Capung Di Bukit Cogong Kabupaten Musi Rawas, Quagga: Jurnal Pendidikan dan Biologi, 12(2), 181-187, doi: 10.25134/quagga.v12i2.2804.

Received: 10-05-2020

Accepted: 24-06-2020

Published: 01-07-2020

\begin{abstract}
Abstrak: Penelitian ini bertujuan untuk mengetahui indeks keanekaragaman jenis capung yang ada di Bukit Cogong kabupaten Musi Rawas. Penelitian ini menggunakan metode eksplorasi dan deskripsi dengan menggunakan teknik menjelajah transek. Stasiun pengamatan ditentukan menjadi 3 stasiun dengan 5 buah transek secara sistematis dengan luas transek $100 \mathrm{~m}$ X 100m. Penangkapan menggunakan jaring serangga, pengidentifikasian dengan melakukan pengamatan ciri-ciri morfologi capung. Berdasarkan penelitian, diperoleh data 112 Individu capung dari 10 Spesies capung dan dari 6 famili capung yaitu Libellulidae, Aeshnidae, Euphaeidae, Protoneuridae, Platycnemididae dan Lestidae. Kelimpahan Relatif yang paling rendah yaitu Gynachanta bayadera dan Nososticta insignis sebesar 1,8\%, sedangkan yang paling tinggi yaitu Orthetrum sabina sebesar. 34,23\%. Indeks keanekaragaman jenis capung di Bukit Cogong Kabupaten Musi Rawas berkategori rendah dengan nilai sebesar 1,96. indeks keseragaman pada seluruh stasiun berkategori tinggi, komunitas stabil dan indeks dominansi $(C)$ pada seluruh stasiun berkategori rendah.
\end{abstract}

Kata Kunci: keanekaragaman, capung, Bukit Cogong

\begin{abstract}
This study was to determine the diversity index of dragonflies in Bukit Cogong Musi Rawas. This study uses exploratory methods and descriptions using techniques to explore transects. The observation station was determined to be 3 stations with 5 systematic transects with an area of $100 \mathrm{~m}$ X $100 \mathrm{~m}$ transect. Catching using net nets, identifying by observing dragonfly morphological characteristics. Based on the research, data obtained from 111 dragonfly individuals from 10 dragonfly species and from 6 dragonfly famiil, namely Libellulidae, Aeshnidae, Euphaeidae, Protoneuridae, Platycnemididae and Lestidae. The lowest relative abundance were Gynachanta bayadera and Nososticta insignis at 1.8\%, while the highest relative abundance was Orthetrum sabina as big as. $34.23 \%$. The diversity index of dragonflies in Bukit Cogong, Musi Rawas was categorized as low with a value of 1.96. the uniformity index for all high-categorized stations, stable communities and dominance index $(C)$ in all stations are categorized as low.
\end{abstract}

Keywords: diversity, dragonflies, Bukit Cogong

\section{PENDAHULUAN}

Hutan secara umum dikenal sebagai suatu sumberdaya yang sangat beragam bagi kehidupan baik secara langsung maupun tidak langsung. Proses-proses interaksi di antara berbagi komponen-komponen penyusunnya bersifat saling meguntungkan dan ketergantugan, sehingga setiap bentuk kehidupan dan ekosistem hutan mempunyai kemampuan berbeda dalam hal pemenuhan kebutuhannya akan kondisi lingkungan termasuk unsur-unsur iklim (Musriadi dkk, 2017). Hutan merupakan salah satu ekosistem yang penting untuk menunjang kehidupan manusia, selain itu pada ekosistem hutan juga terdapat beranekaragam jenis serangga, termasuk capung. Capung di masukkan kedalam ordo odonata, karena mempunyai rahang yang bergigi. Odonata adalah kelompok serangga yang berukuran sedang sampai besar dan seringkali berwarna menarik (Rizal dkk, 2015). Capung itu mempunyai peran yang sangat penting bagi hutan dan kehidupan, dalam ekosistem, capung mempunyai peran yang besar dalam menjaga keseimbangan rantai makanan. Capung berperan sebagai predator serangga kecil lainnya, bahkan kanibal terhadap jenisnya, selain itu capung dapat memangsa nyamuk, lalat 
dan serangga lain yang merugikan sehingga kehadiran capung dalam suatu ekosistem dapat di jadikan indikator keseimbangan ekosistem terbesar terutama hutan (Pamungkas dkk, 2015). Salah satu hutan yang menjadi tempat tinggal capung adalah Bukit Cogong.

Bukit Cogong merupakan suatu hutan yang terbentuk secara alami dan dilestarikan dengan manusia. sumber air Bukit Cogong dari sumber air permukaan, mata air tanah dan air hujan. Pada saat ini pemanfaat Bukit Cogong dijadikan sebagai sumber rekreasi wisata tetapi hanya kurang perawatan saja sehingga membuat peminat untuk mengunjunginya berkurang. Semakin berkembangnya perkembangan kota membuat daerah disekeliling kawasan Bukit cogong yang merupakan hutan alami sekarang telah berubah menjadi tempat pemukiman, bahkan di Bukit Cogong tersebut telah dibangun seperti tempat rekreasi buatan seperti tempat bermain anak-anak, rekreasi (buatan) tetapi hanya kurang perawatan saja. Lingkungan tersebut merupakan habitat yang ideal untuk perkembangbiakan capung (Cahyono, 2013).

Berdasarkan pengamatan yang dilakukan di Bukit Cogong kabupaten Musi Rawas, dengan banyaknya minat wisatawan berkunjung, maka pemerintah gencar melakukan pembangunan di kawasan objek pariwisata untuk menarik minat wisatawan. Adanya pembangunan tersebut dikhawatirkan akan merubah habitat asli terutama keanekaragaman hayati yang berdomisili di area tersebut. Bukit Cogong ini tentunya memiliki kekayaan sumber daya hayati dimana salah satu contohnya yaitu Capung. Hasil observasi yang dilakukan di Bukit Cogong Kabupaten Musi Rawas, bahwa banyak ditemukan jenis-jenis capung. Namun, jenisjenis tersebut belum terdata secara terperinci karena belum pernah dilakukan penelitian untuk mengetahui jenis-jenis capung yang ada di Bukit Cogong Kabupaten Musi Rawas. Selain itu, indeks keanekaragamannya pun belum diketahui. Sehingga, peneliti tertarik untuk melakukan penelitian dengan judul keanekaragaman jenis-jenis capung Di Bukit Cogong Kabupaten Musi Rawas.

\section{METODOLOGI PENELITIAN}

Penelitian ini bersifat deskriptif kualitatif, dimana setiap stasiun pengamatan memiliki 5 buah transek dengan luas tiap transek adalah 100 m x $100 \mathrm{~m}$. Metode deskriptif bertujuan mendeskripsikan sifat atau karakteristik dari suatu peristiwa yang terjadi saat ini (Noor, 2011). Adapun subjek yang akan di jadikan penelitian ini adalah semua jenis-jenis capung yang ditemukan di Bukit Cogong Kabupaten Musi Rawas yang kemudian diamati berdasarkan ciri-ciri morfologinya. penelitian ini menggunakan teknik purposive sampling yaitu peneliti turun langsung menuju ke tempat (area, wilayah, atau lokasi) yang akan diteliti (Sugiyono, 2016).

Berdasarkan data yang telah diperoleh maka akan dilakukan analisis secara deskriptif, yaitu dilihat dari ciri-ciri capung secara morfologi, serta kemudian menjelaskan ciri-ciri yang terdapat pada capung tersebut. Analisis data secara manual meliputi Kelimpahan Relatif $(\mathrm{KR})$, indeks keanekaragaman $\left(\boldsymbol{H}^{\prime}\right)$, indeks keseragaman (E) dan indeks dominansi (Samitra \& Rozi, 2018). Kelimpahan Relatif (KR) adalah jumlah spesies-i per jumlah seluruh total individu yang tertangkap, dengan rumus sebagai berikut :

$$
K R=\frac{n i}{N} \mathbf{X} 100 \%
$$

dimana:

$\mathrm{KR}=$ Kelimpahan Relatif (\%)

$\mathrm{ni}=$ jumlah individu spesies- $\mathrm{i}$

$\mathrm{N}=$ jumlah total individu semua spesies

Sedikit atau banyaknya keanekaragaman spesies dapat dilihat dari indeks keanekaragaman $\left(H^{\prime}\right)$. Keanekaragaman $\left(H^{\prime}\right)$ mempunyai nilai terbesar jika semua individu berasal dari spesies yang berbeda-beda. Indeks keanekaragaman dapat dihitung dengan menggunakan rumus Shannon-Wienner, yaitu:

$$
H^{\prime}=-\Sigma \frac{n 1}{N} \times \ln \frac{n 1}{N}
$$

dimana:

$\mathrm{H}^{\prime}=$ indeks keanekeragaman

$\mathrm{n} 1=$ jumlah individu jenis ke-i

$\mathrm{N}=$ Jumlah individu seluruh jenis

Adapun nilai indeks keanekaragaman dapat dilihat pada tabel 1 . 
Tabel 1. Kriteria Indeks Keanekaragaman

\begin{tabular}{lcc}
\hline \multicolumn{1}{c}{ Indeks } & Nilai & Kategori \\
\hline Ekologi & & \\
Indeks & $\boldsymbol{H}^{\prime} \leq 2,0$ & Rendah \\
Keanekarga & $2,0<\boldsymbol{H}^{\prime} \leq 3,0$ & Sedang \\
man $\left(\boldsymbol{H}^{\prime}\right)$ & $\boldsymbol{H}^{\prime} \geq 3,0$ & Tinggi \\
\hline
\end{tabular}

Semakin besar nilai indeks keseragaman (E) menunjukkan kelimpahan yang hampir seragam dan merata antar jenis. Nilai indeks keseragaman (E) dapat dihitung menggunakan rumus:

$$
\mathrm{E}=\frac{H^{\prime}}{\ln S}
$$

dimana:

$\mathrm{E}=$ indeks kemerataan jenis

$\mathrm{H}^{\prime}=$ indeks keanekeragaman

$\mathrm{S}=$ Jumlah jenis yang ditemukan

Adapun nilai indeks keseragaman dapat dilihat pada tabel 2 .

Tabel 2. Kriteria Indeks Keseragaman

\begin{tabular}{ccc}
\hline $\begin{array}{c}\text { Indeks } \\
\text { Ekologi }\end{array}$ & Nilai & Kategori \\
\hline $\begin{array}{c}\text { Indeks } \\
\text { Keseragaman } \\
(\mathbf{E})\end{array}$ & $\mathrm{E}<0,5$ & $\begin{array}{c}\text { Keseragaman } \\
\text { populasi kecil, } \\
\text { komunitas } \\
\text { tertekan } \\
\text { Keseragaman } \\
\text { populasi sedang, } \\
\text { komunitas labil } \\
\text { Keseragaman } \\
\text { populasi tinggi, } \\
\text { komunitas stabil }\end{array}$ \\
\hline
\end{tabular}

Jika nilai indeks keseragaman mendekati 0 dapat diartikan dalam ekosistem/komunitas tersebut terjadi kecendrungan dominansi spesies tertentu, dan jika nilai mendekati 1 maka ekosistem/komunitas berada dalam kondisi relatif stabil dan penyebaran spesies merata. Indeks dominansi digunakan untuk mengetahui dominansi spesies pada suatu daerah. Indeks dominansi dihitung dengan menggunakan rumus sebagai berikut:

$$
C=\Sigma(n i / N)^{2}
$$

dimana:

$\mathrm{C}=$ indeks dominansi

$\mathrm{ni}=$ jumlah individu spesies-i

$\mathrm{N}=$ jumlah total individu semua spesies

Adapun kategori indeks dominansi dapat dilihat pada tabel 3 .

Tabel 3. Kriteria Indeks Dominansi

\begin{tabular}{lcc}
\hline Indeks Ekologi & Nilai & Kategori \\
\hline Indeks & $0,00<\mathrm{C} \leq 0,5$ & Rendah \\
Dominansi $(\mathbf{C})$ & $0,50>\mathrm{C} \leq 0,75$ & Sedang \\
& $0,75<\mathrm{C} \leq 1$ & Tinggi \\
\hline
\end{tabular}

\section{HASIL DAN PEMBAHASAN}

Berdasarkan hasil penelitian yang dilakukan di Bukit Cogong Kabupaten Musi Rawas diperoleh 10 spesies capung yang berasal dari 6 famili. Data dapat dilihat pada tabel 4 .

Tabel 4. Spesies capung di Bukit Cogong Kabupaten Musi Rawas

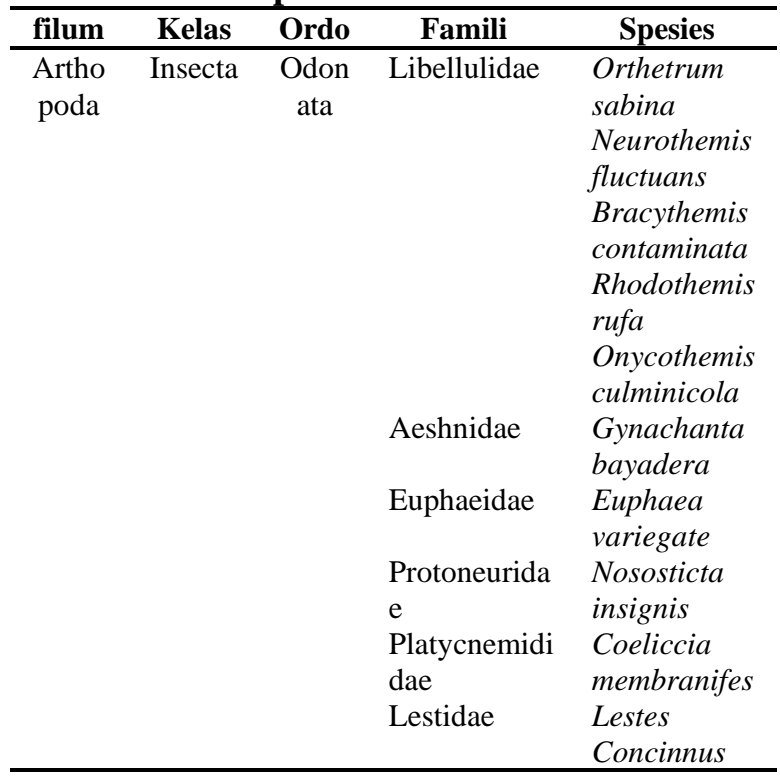

Pada Tabel 4 diketahui bahwa terdapat 10 spesies capung yang berhasil tertangkap yang berasal dari 6 famili yaitu famili Libellulidae, Aeshnidae, Euphaeidae, Protoneuridae, Platycnemididae dan Lestidae. Pada famili Libellulidae spesies yang tertangkap paling banyak yaitu 5 spesies. Sedangkan 5 famili lainnya masing-masing ditemukan 1 spesies. Jumlah individu yang ditemukan di Bukit Cogong sebanyak 112, dari 3 stasiun pengamatan. Data dapat dilihat pada tabel 5. 


\begin{tabular}{ccccc}
\multicolumn{4}{c}{ Tabel 5. Jumlah Inividu capung yang } \\
tertangkap disetiap Stasiun penelitian
\end{tabular}

Berdasarkan tabel diatas, diketahui bahwa, jumlah spesies paling banyak ditemukan di stasiun II. Sedangkan stasiun III adalah stasiun dengan jumlah spesies paling sedikit. Hal ini disebabkan oleh kondisi dari masing-masing stasiun yang mendukung keberadaan spesies. Sedangkan, berdasarkan spesies, stasiun II merupakan stasiun dengan spesies paling banyak yaitu 9 spesies dan stasiun III merupakan stasiun dengan spesies paling sedikit yaitu 7 spesies. Pada stasiun I, II dan III spesies Orthetrum sabina memiliki jumlah paling banyak yaitu 15,17 , dan 6 . Sedangkan spesies paling sedikit yang ditemukan pada stasiun I adalah Onycothemis culminicola dan Coeliccia membranifes. Pada stasiun II, spesies dengan jumlah paling sedikit adalah Nososticta insignis. Sedangkan pada stasiun III, spesies dengan jumlah paling sedikit adalah Nososticta insignis.

Kelimpahan relatif merupakan suatu susunan dan jumlah jenis capung yang tertangkap di Bukit Cogong Kabupaten Musi Rawas. Kelimpahan relatif capung yang tertangkap di dapat dilihat pada tabel 6 dibawah ini.
Tabel 6. Nilai Kelimpahan Relatif

\begin{tabular}{clc}
\hline No & \multicolumn{1}{c}{ Spesies } & $\begin{array}{c}\text { Komposisi Jenis } \\
(\%)\end{array}$ \\
\hline 1. & Orthetrum sabina & 33,9285714 \\
2. & Neurothemis fluctuans & 8,0357143 \\
3. & Bracythemis contaminata & 17,8571429 \\
4. & Rhodothemis rufa & 8,9285714 \\
$\mathbf{5 .}$ & Onycothemis culminicola & 4,4642857 \\
$\mathbf{6 .}$ & Gynachanta bayadera & 1,7857143 \\
$\mathbf{7 .}$ & Euphaea variegate & 8,0357143 \\
$\mathbf{8 .}$ & Nososticta insignis & 2,6785714 \\
$\mathbf{9 .}$ & Coeliccia membranifes & 5,3571429 \\
$\mathbf{1 0}$ & Lestes Concinnus & 8,9285714 \\
\hline
\end{tabular}

Berdasarkan tabel 6 dapat disimpulkan bahwa kelimpahan relatif capung di Bukit Cogong Kabupaten Musi Rawas yang paling tertinggi yaitu pada spesies Orthetrum sabina dengan kelimpahan relatif sebesar 33,93\%. Spesies capung ini termasuk famili Libellulidae. Nilai kelimpahan yang tinggi menunjukkan adanya dominansi jenis tersebut pada lokasi penelitian. Famili Libellulidae adalah pemangsa (predator), spesies ini biasanya agresif, memakan semua serangga. Kanibal libellulid mengkonsumsi semua jenis organisme akuatik dan hama-hama dominan tanaman pangan dan perkebunan dan ukuran tekstur tubuhnya sesuai dikonsumsi capung, seperti larva nyamuk kecil dan serangga lainnya (Siregar, 2016). Orthetrum sabina merupakan predator yang ganas dengan mangsa wereng kutu daun, kupu-kupu lebah, bahkan capung lain atau capung jarum. Spesies ini sangat adaptif, dapat hidup di lingkungan air yang kurang bagus dan hidup soliter, capung ini biasanya hinggap di semak dan ranting kering untuk waktu yang lama, hidupnya juga bisa di suhu yang tinggi dan rendah (Sigit dkk, 2013). Hal ini sesuai dengan pendapat Patty (2006) yang menyatakan bahwa anggota kelompok ini sangat besar jumlahnya, banyak terdapat disekitar kolam dan rawa-rawa. Namun ada juga yang terdapat di daerah persawahan diantaranya adalah Ortherum sabina.

Sedangkan famili yang memiliki kelimpahan relatif paling rendah adalah Aeshnidae. Famili Aeshnidae adalah kelompok capung yang paling besar. Corak warna tubuh yang khas dari famili ini adalah kombinasi warna hitam, biru, hijau dan cokelat. Tempat hinggap yang disukai daun atau ranting yang tinggi (Sigit, dkk. 2013). Jenis capung ini adalah 
yang paling sedikit peneliti temukan dalam penelitian ini. Karena memiliki mobilitas yang tinggi, sehingga capung ini sulit ditangkap. Hal ini sesuai dengan pendapat Kamaludin, dkk. (2013) yang menyatakan bahwa capung ini berukuran besar, berwarna dominan hijau dan coklat dengan bercak biru pada abdomen. Sering bertengger dibawah kanopi pohon dan bambu. Capung ini merupakan penerbang yang cepat, aktif di pagi dan sore hari. Pendapat serupa juga dikemukana oleh Sigit, dkk, (2013), spesies ini hanya ada di pagi hari sedangkan sore hari sulit di temui, dan sering ditemukan terbang dengan kecepatan tinggi di atas permukaan air. Habitatnya hanya di temui di perairan yang bersih, dengan vegetasi rumput, semak, rumpun bambu, dan tanaman bersih. Sedangkan kondisi perairan di Bukit Cogong sekarang sudah berkurang karena adanya pembangunan sumber air PAM, kemudian di kawasan Bukit Cogong vegetasi bambu jauh dari perairan sehingga membuat spesies ini berkurang dan sulit ditemukan.

Indeks keanekaragaman merupakan salah satu dari bagian struktur komunitas capung, dimana indeks keanekaragaman digunakan untuk melihat tingkat keanekaragaman jenis capung di Bukit Cogong Kabupaten Musi Rawas. Indeks kanekaragaman capung di Bukit Cogong Kabupaten Musi Rawas dapat dilihat pada tabel 7.

Tabel 7. Nilai Indeks Keanekaragaman

\begin{tabular}{cccc}
\hline No. & Stasiun & $\begin{array}{c}\text { Nilai Indeks } \\
\text { Keanekaragaman } \\
\text { (H') }\end{array}$ & Kategori \\
\hline 1. & I & 1,72 & Rendah \\
2. & II & 1,92 & Rendah \\
3. & III & 1,82 & Rendah \\
\hline
\end{tabular}

Berdasarkan tabel 7 dapat disimpulkan bahwa hasil analisis indeks keanekaragaman $\left(\mathrm{H}^{\prime}\right)$ pada jenis capung di Bukit Cogong Kabupaten Musi Rawas menunjukan nilai sebesar 1,72 pada stasiun I, kemudian pada stasiun II sebesar 1,92 dan pada stasiun III sebesar 1,82 maka ketiga stasiun tersebut tergolong dalam ketegori rendah. Indeks Keanekaragaman (H') yang berfungsi untuk memperlihatkan seberapa melimpah tingkat keanekaragaman spesies pada masing-masing stasiun. Hal ini menunjukkan bahwa keadaan capung yang ditemukan di Bukit Cogong memiliki produktivitas rendah, sehingga keanekaragamannya tidak dalam keadaan seimbang atau mengalami perubahan. Seperti yang dikemukakan oleh Indriyanto (2012), keanekaragaman jenis suatu komunitas dikatakan tinggi jika komunitas itu disusun oleh banyak spesies. Sebaliknya suatu komunitas dikatakan memiliki keanekaragaman spesies yang rendah jika komunitas itu disusun oleh sedikit spesies dan jika hanya sedikit spesies yang dominan.

Indeks keseragaman merupakan suatu indeks yang digunakan untuk melihat beberapa jenis capung di Bukit Cogong kabupaten Musi Rawas. Indeks keseragaman jenis capung di Bukit Cogong kabupaten Musi Rawas dapat dilihat pada tabel 8 di bawah ini.

\section{Tabel 8. Nilai Indeks Keseragaman}

\begin{tabular}{cccc}
\hline No. & Stasiun & $\begin{array}{c}\text { Nilai } \\
\text { Indeks } \\
\text { Keseraga } \\
\text { man (E) }\end{array}$ & Kategori \\
\hline 1. & I & 0,83 & Tinggi \\
2. & II & 0,87 & Tinggi \\
3. & III & 0,94 & Tinggi \\
\hline
\end{tabular}

Berdasarkan tabel 8 dapat disimpulkan bahwa hasil analisis indeks keseragaman pada jenis capung di Bukit Cogong Kabupaten Musi Rawas menunjukan nilai sebesar 0,83 pada stasiun I kemudian pada stasiun II sebesar 0,87 dan pada stasiun III sebesar 0,94, maka ketiga stasiun tersebut tergolong kedalam kategori keseragaman populasi tinggi. Dengan demikian, dari ketiga stasiun tersebut mempunyai keseragaman populasi yang tinggi dan komunitasnya stabil. Kriteria nilai keseragaman jenis belalang yaitu nilai E mendekati 1 maka penyebaran individu antar jenis relatif sama (Sagala, dkk. 2014). Hal ini sesuai dengan hasil penelitian Insafitri (2010) yang menyatakan bahwa untuk mengetahui keseimbangan komunitas digunakan indeks keseragaman, yaitu ukuran kesamaan jumlah individu antar spesies dalam suatu komunitas. Semakin mirip jumlah individu antar spesies (semakin merata penyebarannya) maka semakin besar derajat keseimbangan 
Indeks dominansi merupakan suatu indeks yang digunakan untuk memperoleh informasi mengenai jenis capung di Bukit Cogong kabupaten Musi Rawas yang mendominansi pada suatu komunitas yang di temukan. Indeks dominansi jenis capung di Bukit Cogong kabupaten Musi Rawas dapat dilihat pada tabel 9.

Tabel 9. Nilai Indeks Dominansi

\begin{tabular}{cccc}
\hline No. & Stasiun & $\begin{array}{c}\text { Nilai } \\
\text { Indeks } \\
\text { Dominansi } \\
\text { (C) }\end{array}$ & Kategori \\
\hline $\mathbf{1 .}$ & I & 0,23 & Rendah \\
$\mathbf{2 .}$ & II & 0,17 & Rendah \\
$\mathbf{3 .}$ & III & 0,18 & Rendah \\
\hline
\end{tabular}

Berdasarkan tabel 9 dapat disimpulkan bahwa hasil analisis indeks dominansi pada jenis jenis capung di Bukit Cogong kabupaten Musi Rawas, pada stasiun I yaitu sebesar 0,23 sedangkan pada stasiun II sebesar 0,18 dan pada stasiun III yaitu sebesar 0,18 . Maka nilai indeks dominansi dari ketiga stasiun tersebut memiliki nilai sama-sama rendah. Hal ini berkaitan dengan indeks keanekaragaman yang juga berkategori rendah. Indriyanto (2012) mengemukakan bahwa suatu komunitas dikatakan memiliki keanekaragaman spesies yang rendah jika komunitas itu disusun oleh sedikit spesies dan jika hanya sedikit spesies yang dominan. Hal ini sesuai dengan hasil penelitian yang hanya memiliki 1 spesies dominan yang ditemukan pada 3 stasiun.

\section{SIMPULAN}

Berdasarkan hasil penelitian, dapat disimpulkan bahwa:

1. Jenis capung yang ditemukan di Bukit Cogong Kabupaten Musi Rawas terdiri dari famili Libellulidae, Aeshnidae, Euphaeidae, Protoneuridae, Platycnemididae dan Lestidae.

2. Kelimpahan relatif yang paling rendah yaitu Gynachanta bayadera dan Nososticta insignis sebesar 1,8\%, sedangkan yang paling tinggi yaitu Orthetrum sabina sebesar. 34,23\%. Indeks keanekaragaman jenis capung di Bukit Cogong Kabupaten Musi Rawas berkategori rendah dengan nilai sebesar 1,96. Indeks keseragaman pada seluruh stasiun berkategori tinggi, komunitas stabil dan indeks dominansi (C) pada seluruh stasiun berkategori rendah.

\section{UCAPAN TERIMAKASIH}

Kami mengucapkan terimakasih kepada Direktorat Riset dan Pengabdian Masyarakat (DRPM) Kementrian Riset Teknologi dan Pendidikan Tinggi Indonesia yang telah mendanai penelitian ini melalui pendanaan Penelitian Dosen Pemula (PDP) Tahun 2019.

\section{REFERENSI}

Cahyono. 2013. Valuasi Ekonomi Hutan Lindung Bukit Cogong. TESIS. Bengkulu. Universitas Bengkulu

Indriyanto. 2012. Ekologi Hutan. Jakarta: PT Bumi Aksara.

Insafitri. 2010. Keanekaragaman , Keseragaman, Dan Dominansi Bivalvia Di Area Buangan Lumpur Lapindo Muara Sungai Porong. Jurnal Kelautan. 3 (1): 54-59.

Kamaludin N, Pamungkas DW, Nugrahaningrum A dan Sigit W. 2016. Mengungkap Potensi Hulu Bengawan Solo. Yogyakarta: Indonesia Dragonfly Society

Musriadi, dkk. 2017. Identifikasi Tumbuhan Paku (Pterydohyta) Sebagai Bahan Ajar Botani Tumbuhan Rendah. Jurnal Pendidikkan Sains. 5 (1): 22-31.

Noor. 2011. Penelitian Kualitatif. Jakarta: PT Rineka Cipta.

Pamungkas, dkk. 2015. Keragaman Jenis Capung dan Capung Jarum (Odonata) di beberapa Sumber Air. Pros Sem Nas Masy Biodiv Indon. 1 (6): 1295-1301.

Patty, N. 2006. Keanekaragaman Jenis Capung (Odonata) di Situ Gintung Ciputat, Tangerang. Skripsi tidak di terbitkan Jakarta: Fakultas Sains dan Teknologi Universitas Islam Negeri Syarif Hidayatullah

Rizal, dkk. 2015. Inventarisasi Jenis Capung (Odonata) Pada Areal Persawahan. BIOMA. 17 (1): 16-20.

Sagala, M. M., dkk. 2014. Distribusi Logam Berat di Perairan Natuna Distribution of Heavy Metals in Natuna Coastal Waters. Jurnal Ilmu dan Teknologi Kelautan Tropis, 6(2): 297-310. 
Samitra, D. \& Rozi, Z., F. (2018). Keanekaragaman Ikan di Sungai Kelingi Kota Lubuklinggau. Jurnal Biota, 4 (1): 1-6.

Sigit W, Feriwibisono B, Nugrahani M P, Putri B dan Makitan T. (2013). Naga Terbang Wendit. Keanekaragaman Capung Perairan Wendit, Malang Jawa Timur. Jawa Timur: Indonesia Dragonfly society. Siregar, dkk. 2016. Keanekaragaman dan Konservasi Status Capung. Jurnal Pertanian Tropik. 3 (1): 25-30.

Sugiyono. (2016). Penelitian Kuantitatif, Kualitatif dan $R$ dan $D$. Bandung: Alfabeta. 